\title{
The Influence of the Covid 19 Virus and Online Learning on the Education System for Islamic Subjects
}

\author{
Arman Syah Putra ${ }^{1^{*}}$, Disniarti ${ }^{2}$, Heriyah Oktaviani ${ }^{3}$, Wulan Sari $^{4}$, Luthfiyah Apriani ${ }^{5}$ \\ ${ }^{1 *}$ Faculty of Computer, STMIK Insan Pembangunan, Banten, Indonesia \\ ${ }^{2345}$ Faculty of Tarbiyah, SekolahTinggiIlmuTarbiyah,PagarAlam, Sumatra Selatan, Indonesia \\ ${ }^{*}$ Corresponding Author: \\ Email: armansp892@gmail.com
}

\begin{abstract}
.
The background of this research is to know the background of the influence of the covid-19 virus and learning online on the education system for Islamic religious subjects whether the covid-19 virus which is now a resident throughout the world affects the learning system in Indonesia, especially subjects Islam and whether online learning media is a very appropriate medium to be applied to the teaching and learning system that exists during the current pandemic. The method used in this research is to use a quantitative method using a survey tool conducted to 100 people who were randomly selected with the survey tool, the data obtained will be able to represent the original data in the field and be able to find out the actual results. The thing that will be found in this research is how to find out the relationship between Covid-19 and the learning system and how this online learning system affects the learning system on Islamic religious subjects. Therefore, what variables affect it can be seen in this study. In this study will produce data that will be able to find out what variables affect Islamic religious subjects, especially the teaching and learning system in Indonesia and what variables affect the current pandemic, therefore variables must be determined carefully and can affect dependent variable.
\end{abstract}

Keyword :The Covid 19 Virus, Online Learning, Education System, Islamic Subjects.

\section{INTRODUCTION}

One of the important lessons in the Indonesian education system is the subject of Islamic religion and Indonesian language education because these 2 subjects are basic subjects that must continue to exist from basic education to higher education[1]. Therefore, the education system must continue to maintain religious subjects and Indonesian language subjects as compulsory subjects that must exist at every level of education. development continues to be carried out so that religious and Indonesian subjects continue to develop along with the times[2].

The current education system uses an online or online method system due to the high spread of the covid 19 virus[3]. Therefore, the government decided that the teaching and learning system will continue to run but is carried out remotely. This system is quite effective because it can limit the spread of the Covid-19 virus. This lesson must be evaluated. Can it still be treated or does it still need changes because all education systems must continue to run even during this covid 19 pandemic, with evaluation, the education system must be carried out continuously even though it is done offline and online. The decision to do offline learning in July 2021 it is quite difficult because the rate of spread of covid-19 is still quite high, therefore the government is still giving leeway to schools to decide to study online or study offline[4]. The problem raised in this study is to find out the variables that affect Islamic religious subjects in the education system in Indonesia. that affect Islamic religious subjects with these variables, it will be known which variables affect Islamic religious lessons in order to improve the current education system[5].In this study using a quantitative method that will take a survey of 100 students who study at an ah school with the topic of Islamic religious subjects whether the variables that affect and are influenced by Islamic religious subjects with the survey method will be able to take data directly from sources that that can be processed so that it can produce new data that can be legally accounted for[6]. In this study will discuss how the influence of the covid 19 virus learning online on the education system for Islamic religious subjects, whether the covid 19 virus affects Islamic religious subjects and whether online learning also affects Islamic religious subjects 
with this research, it can be seen what variables can affect Islamic religious subjects in the education system in Indonesia[7].

The development of the internet today has become a staple in life as a basic need, so the internet cannot be separated from our daily lives for almost 24 hours we cannot be separated from the name internet connection from us learning until we look for entertainment all connected to the internet so you can imagine How much data which is used every day in various fields in order to help humans carry out daily activities Therefore the internet is also used for daily learning and teaching media that is carried out by students or students because it is done online during the covid 19 pandemic[8].

Since covid19 attacked Indonesia, many systems have changed, one of which is the education system implemented which was initially offline to online, therefore many changes have occurred in the education system in Indonesia, but slowly but surely the spread of the Corona virus has begun to be controlled by Minister NadiemMakarim, who wants to opening a school in June 2021 whether this can be used during the spread of covid-19 still cannot be proven only with strict health protocols then all this can be carried out as well as possible[9]. Therefore the level of public awareness must be increased, especially students during face-to-face schooling[10]. Many applications that have been made since covid-19 spread throughout the world with the application of many help in any case with many applications, one of which is the learning and teaching system is very helpful because it can be done anywhere and anytime. Therefore, with a good application and easy to use, the learning and teaching system will be very helpful and the transfer of knowledge from teacher to student will be easier and students can understand the lesson better[11].

The spread of the covid-19 virus is unavoidable, its spread throughout the world to large countries such as the United Kingdom, America and Africa, with this virus, the new world order will change which used to be close together, but with this move, everyone keeps their distance from one another. people with 1 other person, therefore this virus has changed the world a lot, many businesses died because they couldn't walk during the covid-19 virus pandemic, one of the influential ones was in the field of education, education couldn't run normally because it had to be done remotely to avoid spreading this covid-19 virus[12]. The online learning system is used during the current pandemic because this method is a very appropriate method because it can reduce or prevent the spread of the Corona virus which is attacking the whole world. With this method, students will learn from a distance and can learn from anywhere, especially from home with this online learning method, students are required to be active in learning because many students are less active with online learning methods like this[13].

Islamic religious subjects are subjects that must exist from elementary school to college with the existence of Islamic Religious Education, students or students who are studying for education will be able to deepen their religious knowledge even though in public schools are not schools that have a strong religious basis[14]. therefore Religious subjects can be influenced by many variables, especially during the current pandemic, therefore with this research it will be known what variables can affect Islamic religious subjects taught in schools[15].

\section{METHOD}

Based on Figure 1 below, this research uses quantitative methods using survey tools and will be processed with SPSS software[16], so it will be able to produce accurate and accountable data for the authenticity of the data and the data can be used for further research and can answer this research problem.

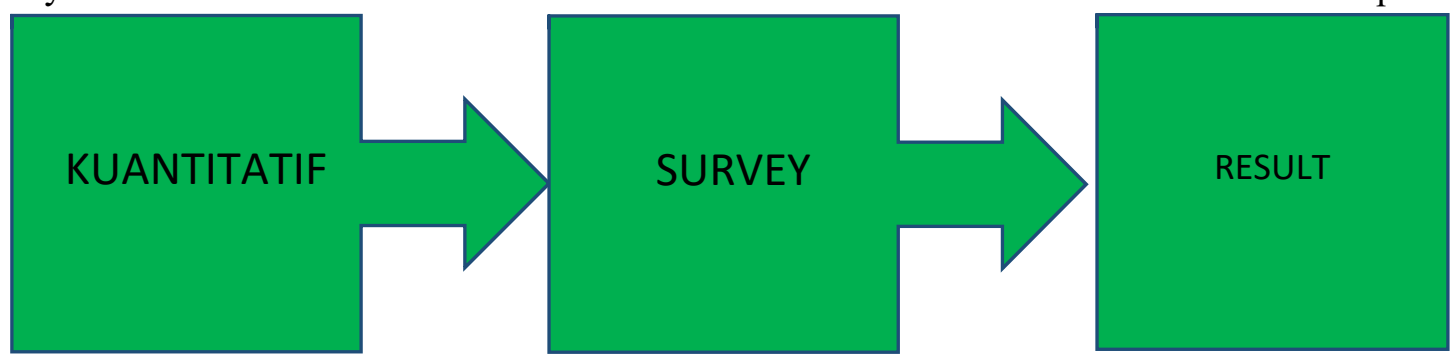

Fig1. Research Method 
Based on the research method above, this study involved 100 people who were selected randomly in order to be able to provide data through a survey that had been conducted to these 100 people. the answers sought from the formulation of the problems raised in this study[17].

\section{RESULT AND DISCUSSION}

Based on Figure 2 below, the following explanation will be given[18], the covid 19 virus will be connected to the education system and is called the 1st hypothesis, then online learning is related to the education system and is called Hypothesis 2[19], then how the education system will relate to the eyes Islamic religious lessons, which is called the third hypothesis, with an image of a model hypothesis like this, it can be seen the direction of the research that was raised at this time[20].

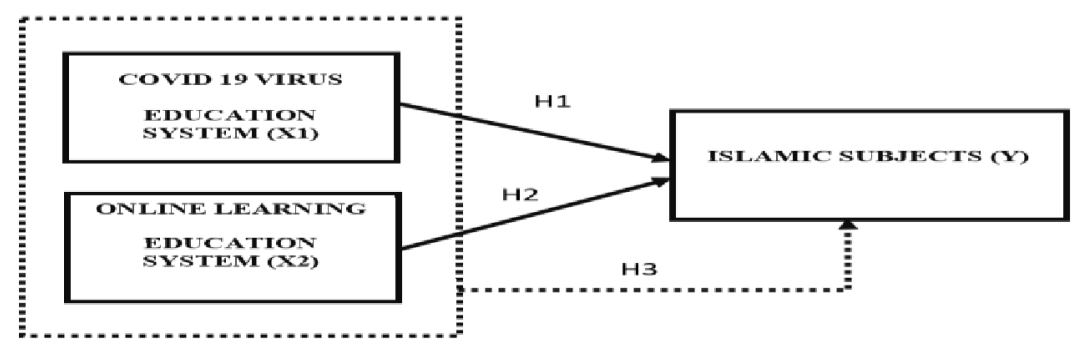

Fig 2. Hipotesis Model

Table 1. Questions on the survey conducted on 100 people

\begin{tabular}{|c|l|c|}
\hline No & \multicolumn{1}{|c|}{ Questions } & Variable \\
\hline 1 & The Covid 19 virus has greatly affected lives & $\mathrm{X} 1$ \\
\hline 2 & The Covid 19 virus affects the education sector & $\mathrm{X} 1$ \\
\hline 3 & The Covid 19 virus is turning online in all aspects & $\mathrm{X} 1$ \\
\hline 4 & Online learning is the right medium at the time of the Covid 19 Virus & $\mathrm{X} 2$ \\
\hline 5 & Online learning makes everyone aware of technology & $\mathrm{X} 2$ \\
\hline 6 & There are still many shortcomings in online learning & $\mathrm{X} 2$ \\
\hline 7 & Learning Islam must be online & $\mathrm{Y}$ \\
\hline 8 & Learning Islam must be offline & $\mathrm{Y}$ \\
\hline 9 & Learning Islamic religion must adapt to circumstances & $\mathrm{Y}$ \\
\hline 10 & Learning Islam can be anywhere & $\mathrm{Y}$ \\
\hline
\end{tabular}

1. Multiple Linear Regression Analysis

a. Regression Equations

Table 2. Recapitulation of the Results of Multiple Linear Regression Analysis

\begin{tabular}{|c|c|}
\hline Variable & Unstandardized Coefficients \\
\hline Covid 19 Virus & 1,342 \\
\hline Online Learning & 0,462 \\
\hline Islamic Subjects & 0,593 \\
\hline
\end{tabular}

Source: The Results of Data Processing

Based on table 2 above, the coefficient result of the Corona virus variable is 1.342 and the online learning variable produces a data coefficient of 0.462 and the Islamic subject variable produces a coefficient of 0.593 .

b.KoefisienDeterminasi (R2)

Table 3. Correlation and Determination Coefficients

\begin{tabular}{|c|c|c|c|c|}
\hline Dependent Variable & $\begin{array}{c}\text { Independent } \\
\text { Variable }\end{array}$ & $\mathrm{R}$ & $\mathrm{R}$ Square & Adjusted R Square \\
\hline $\mathrm{Y}$ & $\mathrm{X} 1 \& \mathrm{X} 2$ & 0,9 & 0,652 & 0,613 \\
\hline
\end{tabular}

Source: The Results of Data Processing 
Based on table 3 above which describes the correlation and efficient determination, it can be concluded that R X1 is 0.9 and R X2 is 41 then it will produce R Square 0.652 but will apply Silk and adjust R Square 0.613 .

c. Hypothesis Testing

c.1. Hipotesis I (F test / Serempak)

Table 4. F / Simultaneous Test

\begin{tabular}{|c|c|c|c|c|c|}
\hline $\begin{array}{c}\text { Dependent } \\
\text { variable }\end{array}$ & $\begin{array}{c}\text { Independent } \\
\text { Variable }\end{array}$ & F Count & F Table 0,05 & Sig.F & decision on H0 \\
\hline $\mathrm{Y}$ & $\mathrm{X} 1 \& \mathrm{X} 2$ & 53,114 & 1,432 & 0,001 & Ditolak \\
\hline
\end{tabular}

Source: The Results of Data Processing

Based on table 4 above, the calculated F Count 53.114 and the F table produces 1.432 and produces a significant $\mathrm{F}$ of 0.001 which results in the hano being rejected so it produces the following data covid 19 affects the learning system on Islamic religious subjects and online learning on the learning system also affects significantly Islamic religious subjects.

c.2Hipotesis II (t test / Parsial)

Table 5. $t$ / partial test results

\begin{tabular}{|c|c|c|}
\hline Variable & $\mathrm{t}$ & Sig. \\
\hline $\mathrm{X} 1$ & 3,298 & 0,002 \\
\hline $\mathrm{X} 2$ & 5,391 & 0,001 \\
\hline
\end{tabular}

Source: The Results of Data Processing

Based on table 5 above which discusses the T-test partially or does not produce the variable $\mathrm{x} 1$ has a $t$ value of 3,298 so that the significant value is 0.002 and the variable $x 2$ has a $t$ value of 5.391 so that the significant value is 0.001 .

2. Discussion of Research Results

a. Hypothesis Covid 19 Virus Has a Significant Effect on Islamic Subjects Partially (H1)

Based on the results of the discussion that resulted in hypothesis 1 (H1), it can be concluded that the covid19 virus has a very significant effect on the Islamic Religion app. The coronavirus covid- 19 spreads in all aspects of life, including the field of education, which is very influential on the daily teaching and learning system.

b. Online Learning has a significant effect on Islamic Subjects partially (H2)

Based on the results of the discussion above, hypothesis 2 (H2) produces very significant results for online learning variables for Islamic religious subjects in the Indonesian learning system. With an online learning system, it will be able to prevent the spread of the Covid 19 virus, which is again very worrying so that it can be prevented online learning system is a learning system that is very appropriate to be applied today.

c. Covid 19 Virus and Online Learning Have a Significant Effect on Simultaneous Islamic Subjects (H3)

Based on the results of the discussion above, hypothesis 3 (H3) produces very significant results on the variable covid 19 virus and online learning of Islamic religious subjects in the Indonesian learning system with an online learning system it will be able to prevent the spread of the covid 19 virus again. its spread is very worrying so that it can be prevented, the online learning system is a learning system that is very appropriate to be applied today.

3. Descriptive Analysis

a. Covid 19 Virus of Using Education System Variables (X1)

Based on the conclusion from the results of the data processing data above, it can be concluded that a Covid 19 Virus (X1) greatly affects the teaching and learning system in Indonesia, with the spread of the Corona virus, all teaching and learning systems have changed. Therefore, the presence of COVID-19 greatly affects the first learning of Islamic religious subjects.

b. Online Learning Variable in Using Education System Variables (X2)

Based on the conclusion from the results of the data processing data above, it can be concluded that Online Learning (X2) greatly affects Islamic religious subjects in schools because with an online learning system that was previously direct it can become an indirect cause of distance between teachers and students. 
c. Islamic Subjects Variable (Y)

Based on the conclusion from the results of the data processing data above, it can be concluded that the Islamic Subjects is strongly influenced by many variables, for example, the Covid-19 virus variable and the online learning system variable with these two variables, it will be known what data can be generated because with this data it can be processed so that conclusions can be drawn what can affect Islamic religious subjects.

\section{CONCLUTION}

The conclusions obtained in this research are the covid 19 virus X1 and online learning X2 and Islamic subjects $\mathrm{Y}$, concluded that the covid-19 virus and the online learning system significantly affected the teaching and learning system, especially Islamic religious subjects, therefore with the data obtained through questionnaires distributed to 100 people randomly and generating new data with the new data, it was concluded that cofid19 affected the teaching and learning system for Islamic religious subjects and online learning systems also affect the teaching and learning system for Islamic religious subjects.

\section{REFERENCES}

[1] A. R. Aditya Nalendra, S. H. Winarno, A. Priadi, E. Hermawan, M. W. Purnomo and A. S. Putra, "The Effect of Goods Prices And Buyer Trust on The E-Commerce Sales System For Purchasing Goods Online," International Journal of Science, Technology \& Management, vol. 2, no. 3, pp. 561-567, 2021.

[2] D. N. M. A. A. P. J. I. D. H. S. Y. C. Arman Syah Putra, "“Examine Relationship of Soft Skills, Hard Skills, Innovation and Performance: the Mediation Effect of Organizational Le," IJSMS, pp. 27-43, 2020.

[3] A. Damuri, N. Isnain, R. A. Priyatama, Y. I. Chandra and A. S. Putra, "E-Learning Proposal System in Public Secondary School Learning," International Journal of Educational Research \& Social Sciences (IJERSC), vol. 2, p. 270-275, 2021.

[4] N. K. Dewi and A. S. Putra, "Perkembangan Gamification dan Dampak Game Online terhadap Jiwa Manusia di Kota Pintar DKI Jakarta," Jurnal Informatika Universitas Pamulang, vol. 5, no. 3, pp. 315-320, 2020.

[5] N. K. Dewi and A. S. Putra, "SISTEM PENUNJANG KEPUTUSAN PENERIMAAN KARYAWAN BARU DENGAN ALGORITMA GREEDY," Jurnal Visualika, vol. 6, no. 2, pp. 154-160, 2020.

[6] N. K. Dewi, I. Mulyana, A. S. Putra and F. R. Radita, "Konsep Robot Penjaga Toko Di Kombinasikan Dengan Pengendalian Virtual Reality (VR) Jarak Jauh," IKRA-ITH INFORMATIKA: Jurnal Komputer dan Informatika, vol. 5, no. 1, pp. 33-38, 2020.

[7] N. K. Dewi and A. S. Putra, "Decision Support System for Head of Warehouse Selection Recommendation Using Analytic Hierarchy Process (AHP) Method," Prosiding International Conference of Universitas Pekalongan, pp. 1-12, 2021.

[8] N. K. Dewi and A. S. Putra, "LAW ENFORCEMENT IN SMART TRANSPORTATION SYSTEMS ON HIGHWAY," Proceedings International Conference onEducation of Suryakancana 2021, pp. 321-326, 2021.

[9] N. K. Dewi, . B. H. Irawan, E. Fitry and A. S. Putra, "Konsep Aplikasi E-Dakwah Untuk Generasi Milenial Jakarta," IKRA-ITH INFORMATIKA: Jurnal Komputer dan Informatika, vol. 5, no. 2, pp. 26-33, 2020.

[10] B. Givan, . R. Wirawan, D. Andriawan, N. Aisyah, A. and A. S. Putra, "Effect of Ease And Trustworthiness To Use E-Commerce for Purchasing Goods Online," International Journal of Educational Research \& Social Sciences (IJERSC), vol. 2, no. 2, p. 277-282, 2021.

[11] M. S. Hartawan, A. S. Putra and A. Muktiono, "Smart City Concept for Integrated Citizen Information Smart Card or ICISC in DKI Jakarta," International Journal of Science, Technology \& Management, pp. 364-370, 2020.

[12] T. Kuncara, A. S. Putra, N. Aisyah and V. Valentino, "Effectiveness of the E-Ticket System Using QR Codes For Smart Transportation Systems," International Journal of Science, Technology \& Management, vol. 2, no. 3, pp. 900-907, 2021.

[13] A. S. Putra and . R. R. Fatrilia, "Paradigma Belajar Mengaji Secara Online Pada Masa Pandemic Coronavirus Disease 2019 (Covid-19)," MATAAZIR: Jurnal Administrasi dan Manajemen Pendidikan, pp. 49-61, 2020.

[14] A. S. Putra and L. H. S. W. Harco, "Intelligent Traffic Monitoring System (ITMS) for Smart City Based on IoT Monitoring," Indonesian Association for Pattern Recognition International Conference (INAPR) IEEE, pp. 161-165, 2018. 
[15] A. S. Putra, L. H. S. W. Harco , S. A. Bahtiar, T. Agung , . S. Wayan and H. K. Chu-, "Gamification in the eLearning Process for children with Attention Deficit Hyperactivity Disorder (ADHD)," Indonesian Association for Pattern Recognition International Conference (INAPR) IEEE, pp. 182-185, 2018.

[16] A. S. Putra, L. H. S. W. Harco , L. G. Ford ,. S. Benfano and A. Edi , "A Proposed surveillance model in an Intelligent Transportation System (ITS)," Indonesian Association for Pattern Recognition International Conference (INAPR) IEEE, pp. 156-160, 2018.

[17] I. Ramadhan, A. Kurniawan and A. S. Putra, "Penentuan Pola Penindakan Pelanggaran Lalu Lintas di DKI Jakarta Menggunakan Metode Analytic Network Process (ANP)," IKRA-ITH INFORMATIKA: Jurnal Komputer dan Informatika, vol. 5, no. 1, pp. 51-57, 2020.

[18] . R. Suryadithia, M. Faisal, A. S. Putra and N. Aisyah, "Technological Developments in the Intelligent Transportation System (ITS)," International Journal of Science, Technology \& Management, vol. 2, no. 3, pp. 837-843, 2021.

[19] . V. H. Valentino, H. S. Setiawan, M. T. Habibie, R. Ningsih, D. Katarina and A. S. Putra, "Online And Offline Learning ComparisonIn The New Normal Era," International Journal of Educational Research \& Social Sciences (IJERSC), vol. 2, no. 2, p. 449-455, 2021.

[20] V. Valentino, H. S. Setiawan, . A. Saputra, Y. Haryanto and A. S. Putra, "Decision Support System for Thesis Session Pass Recommendation Using AHP (Analytic Hierarchy Process) Method," Journal International Journal of Educational Research \& Social Sciences, pp. 215-221, 2021.

[21] N. K. Dewi and A. S. Putra, "Prosiding International Conference of Universitas Pekalongan," Prosiding International Conference on Education of Suryakancana 2021 (ICONNECTS 2021), pp. 321-326, 2021. 